\title{
Aspects of the sustainability of the camel milk value chain and its regulatory framework in Isiolo County, Northern Kenya
}

\author{
Steve N. Machan ${ }^{\text {** }}$ \\ University of Nairobi \\ Jones F. Agwata ${ }^{\text {b }}$ \\ Machakos University \\ Nicholas O. Oguge ${ }^{c}$ \\ University of Nairobi
}

Submitted September 6, 2020 / Revised October 15 and December 17, 2020, and March 16, June 17, August 25, and September 1, 2021 / Accepted September 1, 2021 / Published online February 8, 2022

Citation: Machan, S. N., Agwata, J. F., \& Oguge, N. O. (2022). Aspects of the sustainability of the camel milk value chain and its regulatory framework in Isiolo County, Northern Kenya. Journal of Agriculture, Food Systems, and Community Development, 11(2), 199-216. https://doi.org/10.5304/jafscd.2022.112.007

Copyright (C) 2022 by the Authors. Published by the Lyson Center for Civic Agriculture and Food Systems. Open access under CC-BY license.

\begin{abstract}
The camel milk value chain plays a critical role as a primary foundation of livelihoods among the pastoralist communities, but it faces a great challenge in control mechanisms to enhance a sustainable marketing system. Our study analyzes the drivers and processes influencing the sustainability of the camel milk value chain in Isiolo County, northern Kenya. In this paper, we report on aspects of the
\end{abstract}

a* Steve N. Machan, Centre for Advanced Studies in Environmental Law and Policy, University of Nairobi; P.O. Box 30197-00100; Nairobi, Kenya; +254-725-947-832; smachan2002@yahoo.com

b Jones F. Agwata, Professor of Environmental Sciences, Department of Environmental Sciences, Machakos University, P.O. Box 139-90100, Machakos, Kenya; agwatas@mksu.ac.ke

c Nicholas O. Oguge, Professor of Environmental Policy, Centre for Advanced Studies in Environmental Law and Policy (CASELAP), University of Nairobi; P.O. Box $30197-$ 00100; Nairobi, Kenya; nicholas.oguge@uonbi.ac.ke characteristics of the value chain players and efficacy of its regulatory frameworks, and propose a model for an enhanced system. We conducted the study using primary data from a field survey and obtained secondary data from a desk study. We collected primary data through interviews with households using a survey questionnaire. Using a survey guide, we also conducted key informant

\section{Author Contributions}

This paper is an original work developed by Steve N. Machan (Ph.D. student). Professors Nicholas O. Oguge and Jones F. Agwata have assisted in conceptualization, supervision, original draft preparation, revisions, and have contributed to writing the final text.

\section{Funding Disclosure}

The authors declare that the research was conducted in the absence of any commercial or financial relationships that could be construed as a potential conflict of interest.

\section{Conflicts of Interest}

The authors declare no conflict of interest. 
interviews to supplement the household information. Secondary data was obtained from the literature review. We report that the camel milk value chain has three categories of actors: the microactors (input suppliers, producers, bulking centers, processors, and marketers), the support services providers (e.g., extension services, financial institutions), and the policy-makers who shape the enabling environment of the system. Lack of processing capacity and poor institutional coordination among the chain actors and support institutions were identified as major challenges affecting the sustainability of the camel milk value chain. We present a well-regulated camel milk value chain model for the county with a focus on establishing a camel milk policy to lead to a sustainable system.

\section{Keywords}

Camel Milk, Value Chain, Regulatory Framework, Environment, Northern Kenya

\section{Introduction}

The livestock food system globally contributes significantly to the livelihoods of about one-fifth of the global population (Herrero \& Thornton, 2013; Reay et al., 2020), and most of the world's pastoralists' livelihoods are dependent on livestock production (Downie, 2011; Ndiritu, 2020; Noor et al., 2013). Studies also indicate that by $2050,50 \%$ of the African population will be urban dwellers, and this combined with an anticipated increase in global human population to 9 billion will likely create a growing demand for livestock products worldwide (Willet et al., 2019). In order to address this gap, various food value chain development approaches were developed to identify the underlying concerns. Notably, the Food and Agriculture Organization of the United Nations (Neven, 2014) reports that there are challenges in sustainable food value chains due to dynamic and market-driven systems in which vertical governance and coordination mechanisms are the central dimension. Other studies have also indicated that the constraints to achieving sustainable value chains are due to different phases of production, transportation, processing, and distribution that collectively determine food availability, food access, and food utilization (Colonna et al., 2013; Ingram, 2011; McGinnis \&
Ostrom, 2014); this finding calls for further understanding of the dynamics in these systems to meet the growing market demands.

In sub-Saharan Africa, the Horn of Africa hosts the largest grouping of pastoralists, and more than half the livestock is kept in arid and semi-arid regions of Africa, which occupy almost $70 \%$ of the region (Ndiritu, 2020). In the regions where pastoralism is the major land use system, an estimated 532 million livestock contribute to at least $50 \%$ of total production consumed by the average pastoralist household (Noor et al. 2013). Livestock rearing is considered to be the dominant economic activity in Somalia, Djibouti, Sudan, South Sudan, Kenya, Ethiopia, and Uganda, among others. Hence, livestock value chains play an important role as a primary source of subsistence and other livelihoods for pastoral communities living in drought-prone environments (Demissie et al., 2017).

The Eastern African region is home to $60 \%$ of the world's camel population, and the popularity of camel products, particularly milk, has rapidly increased in recent years, both locally and increasingly in urban areas (Odhiambo, 2013). For Kenya, the livestock subsector contributes $12 \%$ of the total gross domestic product [GDP] and supports the livelihoods of over $80 \%$ of the pastoral communities (Government of Kenya [GOK], 2012, 2017). Specifically, Ndiritu (2020) reports that Kenya's pastoralists occupy vast areas defined as arid and semi-arid lands [ASAL]. These areas account for $84 \%$ of Kenya's land surface area and receive less than $300 \mathrm{~mm}$ (12 inches) of rain per year. Such lands are characterized by long drought spells interspersed with low and erratic rainfall; these weather conditions are worsened by climate change (Harison et al., 2017). A study by Mwanyumba et al. (2015) indicates that camel rearing is an appropriate livestock choice in such fragile environments, since camels are resilient during drought episodes. Camels are a source of food and income, and also provide significant cultural functions to pastoral communities in these arid environments (Noor et al., 2013). According to Behnke and Muthami (2011), Kenya's pastoralist community makes up about $25 \%$ of the country's population and holds over $50 \%$ of the country's 
livestock. Other than providing food and cash income, camels also have a significant role in traditional and cultural functions, and in transport to pastoral communities living in these regions (Kenya National Bureau of Statistics [KNBS], 2020; Noor et al., 2013).

Isiolo County is one of Kenya's major camelkeeping zones, with a camel population of 148,858 and annual milk production of 486 million liters (128 million gallons) in 2019 (KNBS, 2020). The milk is produced in almost all the drier parts of the county and has been found to boost sales and income, cushioning household demand, and also to contribute to the county revenue collection (County Government of Isiolo, 2018). The price of milk at production sites fluctuates between US $\$ .40$ and US $\$ .50^{1}$ per liter and has never been stable (Noor et al., 2013). There are also variations in the quantities of milk supplied depending on the season and availability of grazing resources. This has led to a recognition of local micro-actors in the system, to the need to aggregate and establish formal groups to make their prices more stable, and to open up to wider markets for higher incomes. Among the established groups are two main cooperative societies, Anolei and Tawakal, that were established for the purposes of aggregating, processing, and marketing of camel milk products in order to create a reliable marketing system. These locally established cooperative societies collect fresh milk from different production sites and widely distributed areas, such as Burat, Shaab, Mlango, Merti, Kulamawe, and Garbatulla. Some of the milk is transported from as far as 80 to $120 \mathrm{~km}$ (50 to 75 miles) by motorbikes, and sometimes by donkeys for short distances, posing great challenges to the timely delivery of milk to bulking centers.

Other challenges arise from climate change and subsequent drought episodes, which are on the rise, and few adaptation mechanisms have been put in place. In order to boost the productivity of the livestock subsector, the county plan for putting in place new strategies for modernizing the value chains, including commercializing a camel milk value chain, through the 2018-2022 Isiolo County Integrated Development Plan (CIDP). The overall implication is that there are increasing challenges in the continued production of dairy to meet Kenya's future food requirements (GOK, 2017). This has stimulated increased interest on how to develop a modernized and reliable camel milk value chain system in the county.

\section{Purpose}

Our study investigated the camel milk value chain drivers and processes that influence the viability of the system in Isiolo County in northern Kenya. We established four objectives: (1) examine the socioeconomic characteristics of the households involved in the camel milk value chain, (2) identify characteristics of potential value chain players, (3) evaluate the efficacy of the regulatory frameworks influencing the system, and (4) develop an alternative model for a modernized camel milk value chain with a well-regulated framework for Isiolo County. We used a field survey approach by collecting households' information using questionnaires and key informant interviews using an interview guide. From the survey data, we mapped the camel milk value chain process and identified the different actors involved in the system. We used the results to develop a modernized model for a sustainable camel milk regulatory framework to enhance the system.

\section{Literature Review}

The world food prices crises of 2007, 2008, and 2010 generated increased interest in the analysis of food systems by many policy-makers (Ericksen, 2008a; McGinnis \& Ostrom, 2014). Currently, about 820 million people, mainly from arid and semi-arid regions of the world, have insufficient food (Willett et al., 2019). Studies show that persistent food insecurity, increasing environmental degradation, and poverty levels in the dry lands of sub-Saharan Africa indicate a "food system crisis" (McGinnis \& Ostrom, 2014). In order to remedy

${ }^{1}$ All currencies in this paper are US\$ unless otherwise noted. 
the situation, there is a need for broader levels of engagement in the global policy frameworks to support sustainable value chains (Colonna et al., 2013). These call for multidisciplinary approaches toward the development of potential value chains. Research that analyzes livestock value chains reveals that there is increasing demand for livestock and livestock products both at regional and international levels (Dandesa, 2017; Neven, 2014). Thus, an inadequate marketing system limits the system's ability to meet these needs or requirements to attain national markets.

The FAO (Neven, 2014) defines a sustainable food value chain (SFVC) as the full range of farms and firms and their successive coordinated valueadding activities that produce particular raw agricultural materials and transform them into particular food products which are sold to final consumers and disposed of after use in a manner that is profitable throughout, has broad-based benefits for society, and does not permanently deplete natural resources. These activities or services include input supply, production, bulking, processing, marketing, and final consumption. Such activities can be contained in a single geographical location or spread over more extensive areas (Colonna et al., 2013; Francis et al., 2008). Studies have been conducted of various livestock-based value chains to assess their productivity and market potentials (Colonna et al., 2013; Ericksen, 2008b). The findings of these studies associate the failure of the overall livestockbased food systems to a lack of comprehensive analysis and understanding of potential value chains (Farmer \& Mbwika, 2012). However, no studies have been conducted aimed at understanding the challenges in production and marketing of a camel milk value chain in a pastoralist community practicing nomadic pastoralism, nor that provide an alternative modernized regulatory framework to enhance the system. Previous studies on camel milk value chain have investigated the links in the milk supply chain and overall value chain efficiency (Shukla \& Jharkharia, 2013). For instance, studies done in southern Ethiopia, Somalia, and Saudi Arabia show that the interconnectedness of the camel milk value chain actors is weak and that institutional arrangements are poorly coordinated (Anastasiadis \& Poole, 2015). A study conducted by Mwanyumba and colleagues (2015) indicated that in Kenya's ASALs, there are low levels of milk production, collection, processing, and marketing, and these stages are also not well developed as a result of weak marketing infrastructure characterized by poor marketing facilities and services. Hence, we note that no major studies have been conducted to investigate the regulatory aspects that influence the sustainability of the camel milk value chain. We conducted the present study with the aim of providing adequate information on a camel milk value chain, not only to actors in Isiolo County but also to similar regions undertaking camel milk marketing. Such information would be useful for initiating policy planning and implementing a camel milk value chain.

Specifically, analyses of camel milk value chains indicate that income from the sale of camel milk exceeds other livestock income sources, especially among the pastoralists in northern Kenya (Hussein, 2015; Noor et al., 2013). These studies have been argued that even resource-poor households are involved in the value chain, despite having fewer animals. Studies analyzing camel milk value chains in regions with similar environments, such as Saudi Arabia and eastern Ethiopia, have also mainly looked at the production and marketing of camel milk (Yilma et al., 2017). Many studies have focused mainly on challenges influencing husbandry practices and, to a lesser degree, on the hygienic practices and microbial loads in traditional camel milk production (Ndiritu, 2020; Yilma et al., 2017).

Noor et al. (2013) and Rashid, H. (2014) also report that camel milk value chains have been studied in similar regions in Africa, such as Morocco, Djibouti, Mauritania, Sudan, and Ethiopia. Traditionally, camel milk was consumed either in fresh form or as fermented milk regardless of whether the milk was spoiled (Nato et al. 2018). The study also revealed that traditional milk production methods contribute to increased bacterial loads due to low hygiene practices that subject the product to poor quality and safety standards. The assumption is that the sustainability of a reliable value chain can only be achieved if appropriate social, institutional, and political support can be strengthened to improve the adaptive capacity of the local value 
chain's actors. Studies have pointed out that the development of organized marketing channels and the strengthening of processes that add value to milk would enable camel milk producers to earn more from their stock and guarantee safety and quality to urban consumers (Nato et al., 2018; Farmer \& Mbwika, 2012). Also, Noor et al., 2013 indicates that camel milk is a strong boost for sales, and in certain regions, such as the Middle East, is the driver for intensification of camel dairying. It is, therefore, imperative to note that the challenges in the overall camel milk value chain, particularly in the ASAL of the Sahel and Horn of Africa, are characterized by informal marketing systems (Neven, 2014). This has led to tremendously unpredictable and fluctuating camel milk prices due to an unstable market infrastructure. This lack of an organized marketing system is likely due to a lack of awareness of the prevailing national, regional, and global regulations governing the system.
Ericksen, 2008a indicates that unless local food systems, underlying value chains, and environmental integrity are strengthened, information for designing interventions to protect value chain actors and limit their vulnerability may not be effective in the policy-making process. Thus, inappropriate market regulatory mechanisms have great impact on productivity, market access, and price stability (Colonna et al., 2013). One of the recommendations for improving the camel milk value chain is to carry out research to understand the dynamics of the enabling environment that support the system (Colonna et al., 2013; Ericksen, 2008a; McGinnis \& Ostrom, 2014).

\section{Research Methods}

\section{Background of the Study Area}

The study area, Isiolo County, has a land area of $25,350.6 \mathrm{~km}^{2}$ and a population of 268,002 persons

Figure 1. The Location of the Study Area in Kenya

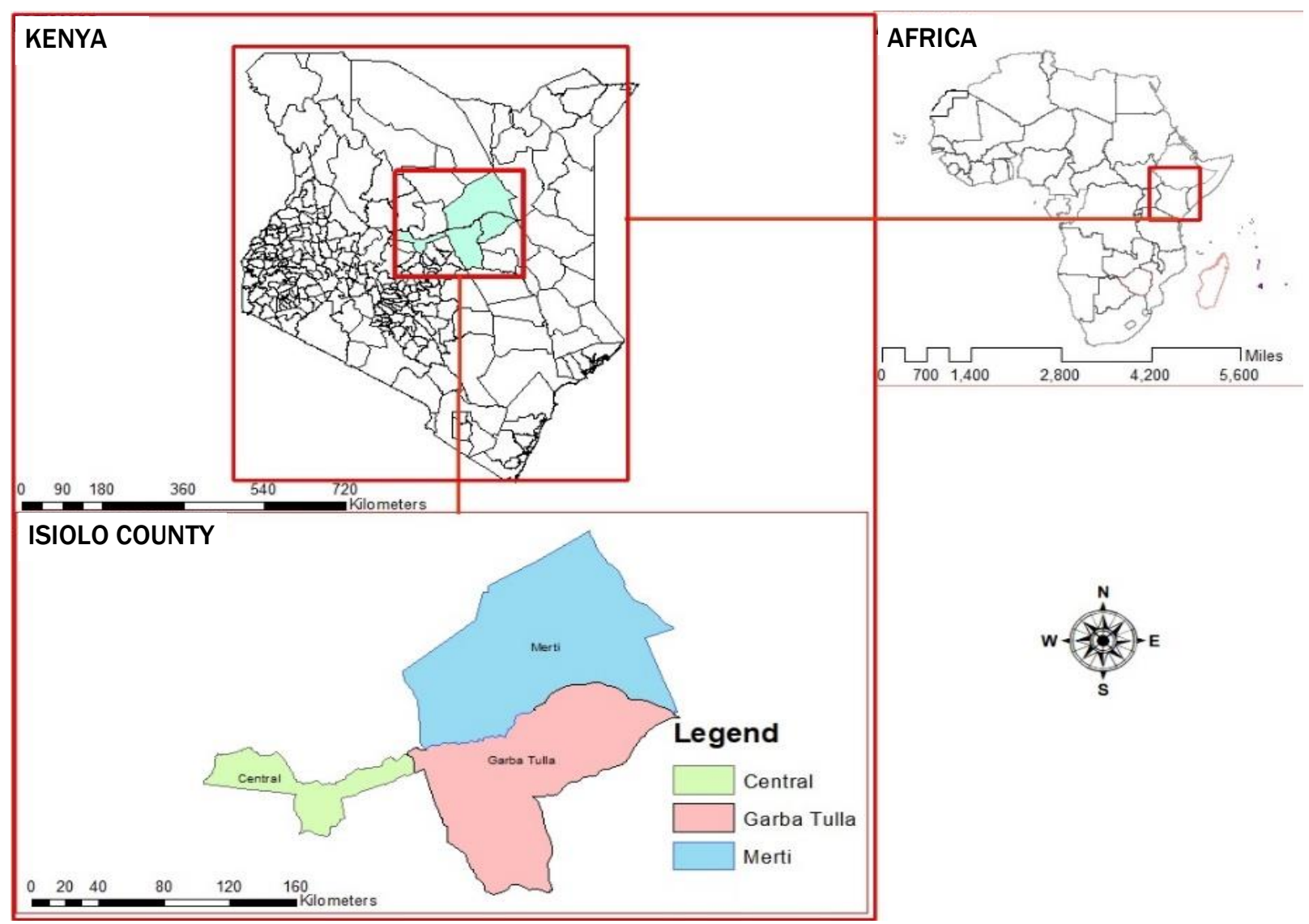


(KNBS, 2020) (Figure 1). Administratively, the county is divided into three sub-counties: Isiolo central, Garbatulla, and Merti. According to the 2019 census, Isiolo central had the highest population, with 121,066 persons, Garbatulla had 99,730 persons, and Merti had the lowest population with 47,206 persons. In terms of climate and land-use system, Isiolo County is a typical arid and semi-arid region with a bimodal rainfall pattern, characterized by long rains from March to May, and short rains from October to December (Nato et al., 2013, 2018; Noor et al., 2013). The temperatures are high throughout the year, ranging from a mean minimum of $27^{\circ} \mathrm{C}$ and a maximum of $30^{\circ} \mathrm{C}$, in almost all parts of the county (Nato et al., 2018). About $95 \%$ of the county is classified as arid or very arid, while only $5 \%$ is semi-arid, generally receiving an average annual rainfall below $300 \mathrm{~mm}$ (12 inches), which is also unevenly distributed (National Drought Management Authority, Ministry of Devolution and Planning, 2015). The topography of the landscape influences the amount of rainfall received; slightly higher areas receive relatively more rainfall due to the influence of Mount Kenya and Nyambene Hills in the neighboring Meru County. Generally, this type of rainfall supports grassland, dry land trees, and shrubs.

In these areas, keeping livestock is the main economic activity for over $80 \%$ of the population and also offers a source of livelihood for the citizens of Isiolo County. The main livestock kept are sheep, goats, cattle, and camels (County Government of Isiolo, 2018). Among the livestock-based value chains in the county, camel milk is the most common enterprise. The value chain also attracts the most vulnerable groups, such as women and youth, into the system.

The majority of land is communally owned $(80 \%)$; public land and wildlife conservancies account for $19 \%$ and only $1 \%$ of the land is privately owned. Over $80 \%$ of the rural population is dependent on camel milk produced under the dominant, traditional production system (County Government of Isiolo, 2018). The system supports the livelihoods of these pastoral communities either directly or indirectly through the value chain. Although the support is significant, the sustainability of the system has not been well understood.
Overall, the camel milk value chain is a major boost in county revenue compared to other livestock-based value chains, but the chain is not well connected. Although there are many interested stakeholders in the value chain, and county regulatory frameworks governing the system, the value chain system still experiences low productivity and an informal market infrastructure. However, there are opportunities for understanding and establishing a reliable camel milk value chain system with a well-structured regulatory framework to enhance the sustainability of the system.

\section{Data Collection Method}

Both primary and secondary data were collected using quantitative and qualitative research methods from camel milk value chain actors. Specifically, surveys, observations, key informant interviews, and desk reviews were conducted. We conducted a survey using questionnaire for collecting quantitative data from the selected households involved in the camel milk value chain. The survey was carried out in the three sub-counties of Isiolo County (Isiolo central, Garbatulla, and Merti) between January and December 2019. We conducted faceto-face interviews and used the telephone for clarification of certain information during data collection and field observations. The interviews were conducted at the village level with selected households. A household head was considered to take part in the interview if the individual was 18 years or older. To gather information on the fresh milk supplied, milk processed, and milk marketed, we conducted interviews at the camel milk bulking and processing centers in the county.

Data on the drivers of the studied camel milk value chain included the socio-demographic and socio-economic characteristics of the value chain players. We collected information on the sex of the household heads involved in a camel milk value chain, level of education of household heads, and quantities of milk supplied along the value chain system. Primary data were collected to provide insights on the characteristics of the camel milk value chain players based on their socio-demographic and socio-economic characteristics and the efficacy of the regulatory frameworks influencing the system. Records on the quantities of milk supplied to 
bulking centers and processing units were obtained mainly from the two active cooperative societies (Anolei and Tawakal). During the survey, we used different interview guides for each category of actors. For example, in the case of input suppliers, we collected information on the kind of services they offered to support the system. In the case of producers, we gathered information on the amount of milk produced at the household level and the surplus for sale or delivery to bulking centers. For processors and marketers, we collected information from their records to estimate the quantities of milk supplied, processed, and marketed. Specifically, the types and numbers of value chain actors interviewed included input suppliers (31), producers (110), bulking centers (18), processors (104), marketers (39), and consumers (50).

In terms of processes influencing the sustainability of the camel milk value chain, we collected data from all the actors on the levels of awareness of existing camel milk regulatory frameworks influencing the system. In addition, desk reviews were used to collect qualitative data on past records from public institutions, such as the livestock department, veterinary department, public health department, and relevant development agencies, to add value to the statistical analysis and to check for bias. The survey adopted the open data kit (ODK) design for use in a mobile data platform. Data were collected through an Android platform running on tablets to ensure validity and reliability of the data. Trained local enumerators who spoke the language of the respondents administered the questionnaires during the survey. We conducted pretesting of the questionnaires for data collection to remove errors and to assure data quality.

\section{Sampling}

In order to establish the number of households participating in a camel milk value chain in the county, we consulted the county administrators, including chiefs and village heads, who provided data on 1,100 households. Using the simple random sampling method with the aid of the Raosoft sample size calculator for the determined target population, 316 households were randomly selected for interviews. We adopted the probability-proportional-to-size (PPS) sampling tech- nique to get the actual sample size by sex and age and disaggregated them into input suppliers, producers, traders, transporters, and consumers. We selected key informants $(n=20)$ using the snowball purposive sampling technique based on their knowledge of the camel milk value chain system. These data types were necessary to complement one another so as to reduce the biases and weaknesses in both quantitative and qualitative methods. The respondents for the selected households and key informants were contacted, briefed about the research, and asked for their consent as stipulated by research ethics. The information collected from KII's and field observations were recorded in a Microsoft Word document and summarized into narratives; hence they were not included in the statistical data.

\section{Data Analysis}

Data were entered into a Microsoft Excel spreadsheet for cleaning and then transferred to IBM SPSS Statistics for Windows (Version 23.0.0). We analyzed data on the socio-demographic and socioeconomic information of the household heads interviewed, quantities of milk supplied, mapping of the camel milk value chain system using the information provided by respondents, categories of support institutions, and levels of awareness on regulatory frameworks by value chain microplayers. In these we used the household head as the unit of analysis. We computed measures of central tendency (mean) and dispersion (range) to summarize the socio-demographic and socio-economic data. The perceptions of the levels of awareness of regulatory aspects were analyzed using descriptive statistics. In this case, the simple response variable may add up to a maximum of $100 \%$. We collected data on the total quantities of milk supplied by producers to bulking centers in 2018 and used descriptive statistics to get the means. The milk measurements were given in the form of liters. The secondary data from the literature review provided supplementary information and support. A combination of these analyzes was then used for interpretation and also provided opportunity for researchers' triangulation to develop a modern camel milk value chain regulatory framework for the county. 


\section{Results}

\section{Socio-demographic and Socio-economic Characteristics of the Respondents}

The results show that $62 \%$ of the total respondents in all categories had no formal education and none had university education (Table 1). The study also showed that female respondents were the most disadvantaged in education, indicating $45 \%$ with informal education, $18 \%$ with primary education, $6.3 \%$ with secondary level education, and none with either tertiary or university education. The education level of male respondents was also recorded at $17 \%$ with no formal education, $7.4 \%$ primary, $4.6 \%$ secondary, while $1.4 \%$ had tertiary.

\section{Average Camel Milk Data Collected by the Bulking Centers (2014-2019)}

The results of the milk data collected from the bulking centers over the six-year period indicate that an average of $1,727,834$ liters of milk were generated in the county annually (Table 2 ). Out of this, 1,465,911 liters $(85 \%)$ were delivered on average to the bulking centers annually, and thus to the local processors. About 261,922 liters (15\%) of the milk produced was consumed at the household level. We also found that 293,182 liters (20\%) of the milk delivered to processors spoiled or became wastage. The value addition of milk at the county is low, standing at 74,362 liters (5\%) annually.

The results also indicate that the average sales of milk across 6 years was $\$ 829,360$, processed fresh milk delivered to bulking centers was $\$ 1,172,729$, and milk processed into yoghurt was $\$ 100,339$ annually (Table 3). If the cooperative societies could process all the fresh milk into yoghurt, it would be valued at $\$ 1,978,980$, compared to the current value of $\$ 1,172,729$ offered at the processing centers. This is a $68 \%$ increase in total revenue earnings annually.
Table 1. Response Rate by Sex and Education of the Respondents Involved in a Camel Milk Value Chain

\begin{tabular}{lccc}
\hline & \multicolumn{3}{c}{ Sex of the respondents } \\
\hline $\begin{array}{l}\text { Level of education of the } \\
\text { respondents }\end{array}$ & Male $(\boldsymbol{n = 8 6 ) ( \% )}$ & Female $(\boldsymbol{n = 1 9 8 )}(\%)$ & Total $(\boldsymbol{n}=\mathbf{2 8 4}), \%$ \\
\hline No formal education & $48(17)$ & $128(45)$ & $62.0 \%$ \\
Primary & $21(7.4)$ & $52(18)$ & $25.4 \%$ \\
Secondary & $13(4.6)$ & $18(6.3)$ & $10.9 \%$ \\
Tertiary & $4(1.4)$ & $0(0)$ & $1.4 \%$ \\
University & $0(0)$ & $0(0)$ & $0(0)$ \\
\hline
\end{tabular}

The nominal values show the number who responded, while the figures in parentheses show the frequency in the levels of education (\%).

\section{Mapping the Camel Milk} Value Chain in Isiolo County, Kenya

We used the data displayed in Table 3 to map the flow of products from the point of production to consumption. The flow chart (Figure 2) provides a clear movement of products from the point of production to final consumption points and the points of intervention by support services providers and the

Table 2. Quantities of Camel Milk Produced in the County During 2014-2019

\begin{tabular}{lccccc}
\hline $\begin{array}{l}\text { Period } \\
\text { (Year) }\end{array}$ & $\begin{array}{c}\text { Quantity of fresh milk } \\
\text { produced (liters) }\end{array}$ & $\begin{array}{c}\text { Milk consumed at } \\
\text { household level }\end{array}$ & $\begin{array}{c}\text { Milk delivered to } \\
\text { bulking centers }\end{array}$ & Spoiled milk (liters) & $\begin{array}{c}\text { Processed milk into } \\
\text { yoghurt (liters) }\end{array}$ \\
\hline 2014 & $1,687,900$ & 286,943 & $1,400,957$ & 266,182 & 56,038 \\
2015 & $1,626,230$ & $260,196.8$ & $1,366,033.2$ & 245,886 & $61,471.5$ \\
2016 & $1,702,912$ & $272,465.92$ & $1,430,446.08$ & 271,789 & 71,523 \\
2017 & $2,011,924$ & $301,788.6$ & $1,710,135.4$ & 498,223 & $119,709.5$ \\
2018 & $1,619,662$ & $226,752.68$ & $1,392,909.32$ & $222,865.5$ & 62,681 \\
2019 & $1,718,374$ & $223,388.62$ & $1,494985.38$ & $254,147.5$ & 74,749 \\
\hline Total & $\mathbf{1 0 , 3 6 7 , 0 0 2}$ & $\mathbf{1 , 5 7 1 , 5 3 6 . 0 0}$ & $\mathbf{8 , 7 9 5 , 4 6 6}$ & $\mathbf{1 , 7 5 9 , 0 9 3}$ & $\mathbf{4 4 6 , 1 7 2}$ \\
\hline Average & $\mathbf{1 , 7 2 7 , 8 3 4}$ & $\mathbf{2 6 1 , 9 2 2}$ & $\mathbf{1 , 4 6 5 , 9 1 1}$ & $\mathbf{2 9 3 , 1 8 2}$ & $\mathbf{7 4 , 3 6 2}$ \\
\hline
\end{tabular}


Table 3. Milk Sales from 2014-2019

\begin{tabular}{|c|c|c|c|c|c|c|c|c|c|}
\hline $\begin{array}{l}\text { Period } \\
\text { (year) }\end{array}$ & $\begin{array}{c}\text { Quantity of } \\
\text { milk produced } \\
\text { (liters) }\end{array}$ & $\begin{array}{l}\text { Farmgate } \\
\text { prices (per } \\
\text { liter, US\$) }\end{array}$ & $\begin{array}{l}\text { Total amount } \\
\text { (US\$) }\end{array}$ & $\begin{array}{c}\text { Processed } \\
\text { fresh milk } \\
\text { (liters) }\end{array}$ & $\begin{array}{c}\text { Price } \\
\text { (per liter, } \\
\text { US\$) }\end{array}$ & $\begin{array}{l}\text { Total amount } \\
\text { (US\$) }\end{array}$ & $\begin{array}{l}\text { Processed } \\
\text { yoghurt } \\
\text { (liters) }\end{array}$ & $\begin{array}{c}\text { Price } \\
\text { (per liter } \\
\text { (US\$) }\end{array}$ & $\begin{array}{l}\text { Total } \\
\text { amount } \\
\text { (US\$) }\end{array}$ \\
\hline 014 & $\$ 87,900$ & .50 & & 1,400 & .10 & 980,6 & 56,038 & 1.20 & \\
\hline 2015 & 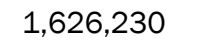 & . & ע & 1,366,033.2 & .10 & $956,223.3$ & $61,471.5$ & $1 . \angle 0$ & $73,765.8$ \\
\hline 2016 & $1,702,912$ & .40 & $681,164.8$ & $1,430,446.08$ & .80 & $1,144,372.9$ & 71,523 & 1.30 & $92,979.9$ \\
\hline 2017 & $2,011,924$ & .40 & $804,796.6$ & $1,710,135.4$ & .80 & 1,368,108.3 & $119,709.5$ & 1.40 & $167,593.3$ \\
\hline 2018 & $1,619,662$ & .50 & 809,831 & 1,392,909.32 & .90 & $1,253,618.4$ & 62,681 & 1.50 & $94,021.5$ \\
\hline 2019 & $1,718,374$ & .60 & $1,031,024.4$ & $1,494,985.38$ & .90 & $1,345,486.9$ & 74,749 & 1.50 & $112,123.5$ \\
\hline verag & $1,727,834$ & .48 & $829,360.3$ & $1,465,911$ & .80 & $1,172,728.8$ & 74,362 & 1.35 & $100,388.7$ \\
\hline
\end{tabular}

Figure 2. A Schematic Presentation of the Analysis of a Typical Camel Milk Value Chain in Isiolo County, Northern Kenya

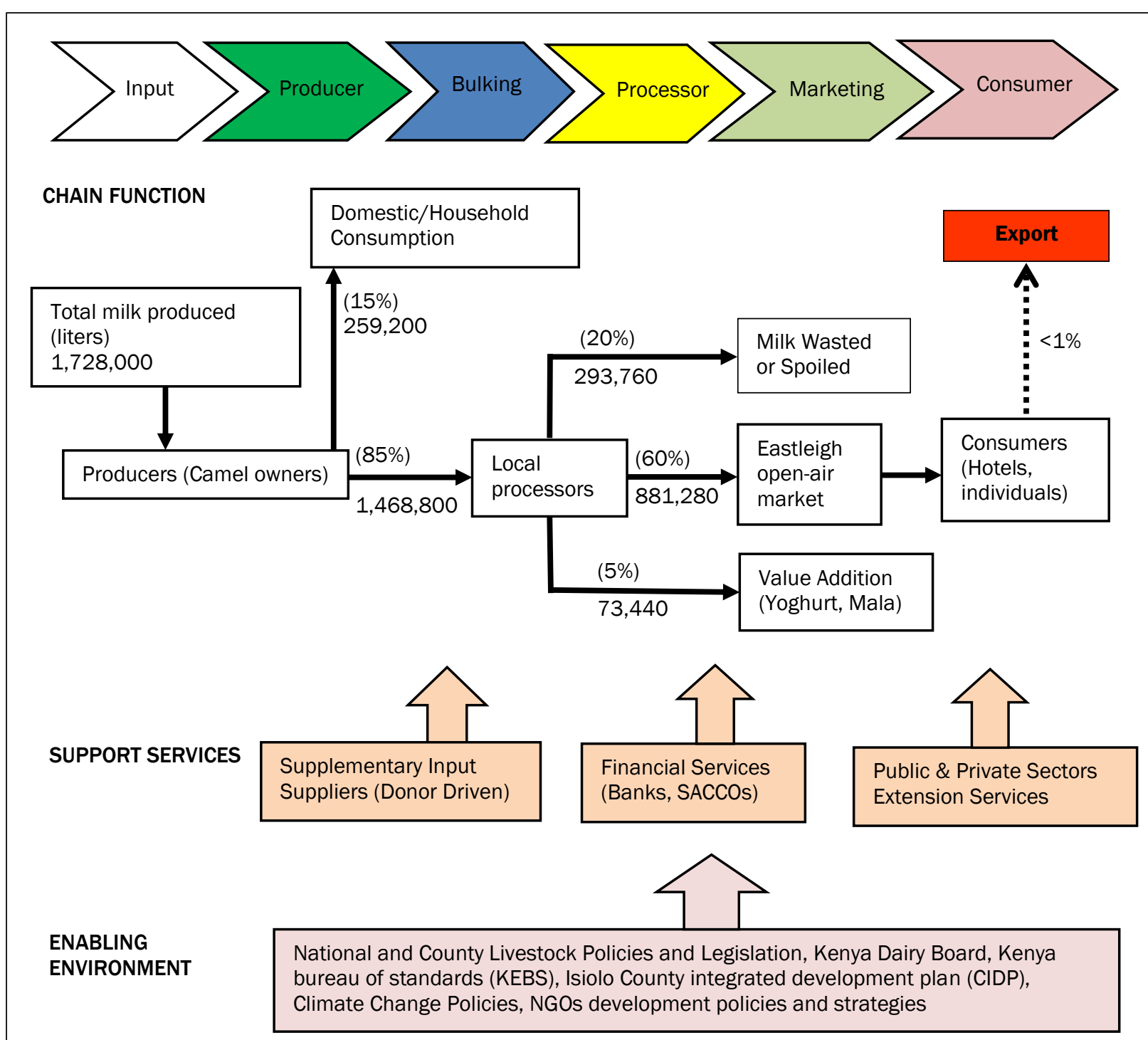


policy-makers who provide the enabling environment for the system. We show that the chain function is disaggregated into input suppliers, producers, milk aggregators, processors, marketers, and finally consumers. Figure 2 shows how milk flows from the point of production to the end and the points of intervention by support services providers and the policy-makers who provide the enabling environment for the system. Sixty percent of the milk traded ends up in the Eastleigh open-air market in the form of raw milk. High milk spoilage and wastage occurs at the production and transportation stages before reaching the processing centers. The support services providers include financial institutions, such as local banks and savings and credit cooperative societies (SACCOs), and general public and private advisory services for livestock production. The regulatory frameworks influencing the enabling environment for a sustainable camel milk value chain include national livestock policies, the national Kenya Dairy Board (KDB), Kenya Bureau of Standards (KEBS), Isiolo County integrated development plan (CIDP), and climate change policies and strategies.

\section{Categories of Support Institutions Involved in the Camel Milk Value Chain in Isiolo County}

The results indicated various stakeholders who provide support services to enhance the develop- ment of the camel milk value chain in the county (Figure 3). The results of the respondents' surveys on the role played by each actor indicated that the major services offered to the camel milk value chain are provided by the county government at $27.5 \%$ and local nongovernmental organizations (NGOs) at $20.5 \%$, together contributing up to $49 \%$ of the services. The rest include the community $(18.1 \%)$, international development agencies $(17 \%)$, national government (14.6\%), and the local community-based organizations at $2.3 \%$. When the respondents were asked to share their experiences working with these players, $82.5 \%$ indicated weak networking and poor coordination mechanisms. However, $17.5 \%$ of the respondents noted that the existing institutions somehow work together, while reiterating that they are poorly coordinated.

\section{Awareness of the Actors in the Existing Camel Milk Value Chain Regulatory Frameworks}

The producers are most disadvantaged, indicating a high level of lack of awareness in regulatory frameworks, existing policies, and legislation influencing the camel milk value chain in the county (Table 4). Specifically, there is low awareness of national livestock and dairy policies influencing the chain. The findings also showed the micro-actors lack awareness of the regulatory bodies and legislation that influence the system. The level of lack of aware-

Figure 3. Perception of Actors on the Level of Support Services Offered by Varied Stakeholders in the Camel Milk Value Chain

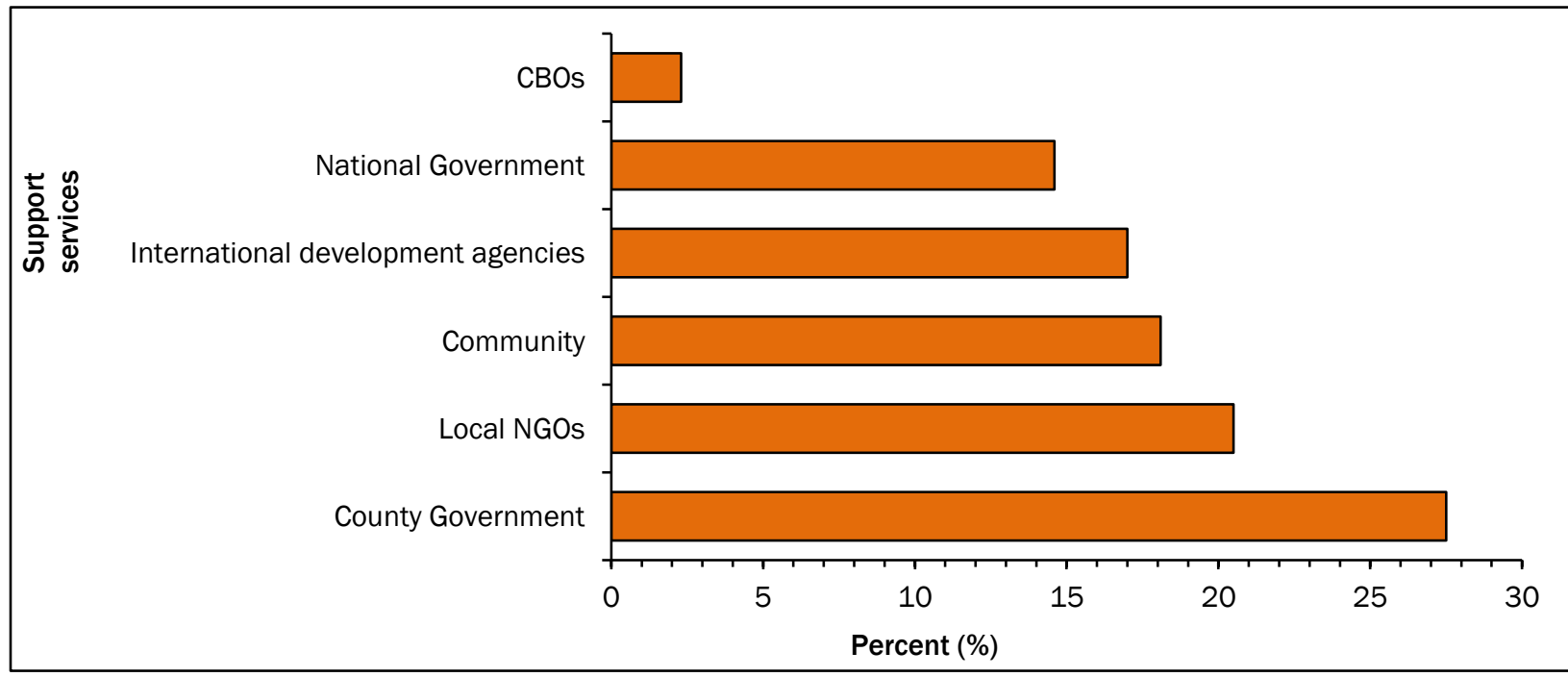


ness by producers of the consumers was found to be $84 \%$, transporters $69 \%$, bulking centers $67 \%$, and producers $62 \%$ (Table 4 ).

\section{Discussion}

Our study reveals a distinct camel milk value chain with three categories of actors. These include the micro-actors involved in daily activities, such as input suppliers, producers, bulking, processors, marketers, and consumers; the support services providers; and those who provide the enabling environment-the policy-makers. Out of the total respondents sampled for interviews, the majority were female respondents $(65 \%)$, and among them majority $(58 \%)$ had no formal education. However, even without much education, the participation of females in the camel milk value chain is instrumental, mainly in the bulking and processing of camel milk products. The respondents selected for KII were not included in these statistics.

Our study shows that $85 \%$ of the camel milk is sold in raw form to the bulking and local processing centers, while only $15 \%$ is consumed at the household level. This is an indication that there is change from the previous traditional practices, where camels were only kept for milk consumed at the household level, to a commercialized system where camel milk is now traded to generate income

Table 4. Respondents' Awareness of Various Legislation, Policies and Regulatory Frameworks

\begin{tabular}{|c|c|c|c|c|c|c|}
\hline \multirow[b]{2}{*}{ Awareness } & \multicolumn{6}{|c|}{ Value chain player } \\
\hline & $\begin{array}{l}\text { Input supplier } \\
(\%)\end{array}$ & $\begin{array}{l}\text { Producer } \\
\text { (\%) }\end{array}$ & $\begin{array}{c}\text { Bulking } \\
\text { center } \\
(\%)\end{array}$ & $\begin{array}{l}\text { Processor } \\
\text { (\%) }\end{array}$ & $\begin{array}{l}\text { Transporters } \\
\text { (\%) }\end{array}$ & $\begin{array}{c}\text { Consumers } \\
(\%)\end{array}$ \\
\hline \multicolumn{7}{|l|}{ Existing regulatory frameworks } \\
\hline Kenya Dairy Board (KDB) & $21(68)$ & $42(38)$ & $6(33)$ & $79(76)$ & $12(31)$ & $8(16)$ \\
\hline Kenya Bureau of Standards (KEBS) & $9(29)$ & $65(59)$ & $15(83)$ & $50(48)$ & $27(69)$ & $19(38)$ \\
\hline $\begin{array}{l}\text { National Environmental } \\
\text { Management Authority (NEMA) }\end{array}$ & $5(16)$ & $32(29)$ & $8(44)$ & $24(23)$ & $29(74)$ & $18(36)$ \\
\hline Public Health & $26(84)$ & $52(47)$ & $18(100)$ & $84(81)$ & $32(82)$ & $22(44)$ \\
\hline \multicolumn{7}{|l|}{ Existing policies } \\
\hline National livestock policy (NLP) & 7 ( (23) & $28(26)$ & $15(83)$ & $80(77)$ & $29(74)$ & $8(16)$ \\
\hline National dairy policy (NDP) & $9(29)$ & $2((2)$ & $3(17)$ & $31(30)$ & $9(23)$ & $11(22)$ \\
\hline $\begin{array}{l}\text { Sustainable Development Goals } \\
\text { (SDGs) }\end{array}$ & $7(23)$ & $15(14)$ & $2(11)$ & $22(21)$ & $10(26)$ & $18(36)$ \\
\hline \multicolumn{7}{|l|}{ Existing legislation and laws } \\
\hline The Constitution of Kenya, 2010 & $15(48)$ & $38(35)$ & $12(67)$ & $85(82)$ & $32(82)$ & $32(64)$ \\
\hline The Dairy Industry Act & $11(36)$ & $40(36)$ & $15(83)$ & $76(73)$ & $14(36)$ & $13(26)$ \\
\hline Public Health Act & $28(90)$ & $40(36)$ & 15 ( (83) & $76(73)$ & $14(36)$ & $13(26)$ \\
\hline Standards Act & $6(19)$ & $42(38)$ & $16(89)$ & $90((87)$ & $30(77)$ & $41(82)$ \\
\hline $\begin{array}{l}\text { Food, Drugs and Chemical } \\
\text { Substances Act }\end{array}$ & $23(74)$ & $18(16)$ & $11(61)$ & $83(80)$ & $28(72)$ & $14(28)$ \\
\hline Animal Diseases Act & $18(58)$ & $36(33)$ & $16(89)$ & $80(77)$ & 31 (79) & $21(42)$ \\
\hline $\begin{array}{l}\text { Environmental Management } \\
\text { Coordination Act (EMCA) }\end{array}$ & $10(31)$ & 79 ( 72) & $18(100)$ & $92(89)$ & $39(100)$ & $37(74)$ \\
\hline $\begin{array}{l}\text { Isiolo County Livestock Sales Yard } \\
\text { Act, } 2016\end{array}$ & $8(26)$ & $20(18)$ & $7(39)$ & $14(14)$ & $14(36)$ & $6(12)$ \\
\hline $\begin{array}{l}\text { Isiolo County Climate Change and } \\
\text { Adaptation Act, } 2017\end{array}$ & $6(19)$ & $10(9)$ & $10(9)$ & $28(27)$ & $18(46)$ & $11(22)$ \\
\hline
\end{tabular}

The nominal values represent those who responded yes, while figures in parentheses show the frequency in the levels of awareness (\%). 
and other livelihood options. Milk spoilage (20\%) occurs at bulking centers and during transportation and is a major concern for a modern camel milk value chain. This has been associated with the long distances to delivery points and poor road infrastructure, inadequate milk production and handling techniques, and lack of milk cooling apparatus. The milk bulking centers and processors have conveyed their great concern to local milk producers due to challenges pertaining to clean milk production and adherence to milk quality and safety measures. The local producers as well as the majority of milk bulking centers are still resistant to adopting modern milk production methods. There continues to be a broad use of locally fumigated milking containers, or "jerry cans," for milking camels and transporting milk to destination markets. For example, $60 \%$ of the milk is sold to milk vendors at the Eastleigh open-air market in Nairobi and a few neighboring markets. We also observed that vendors at these markets prefer milk preserved in traditionally fumigated containers due to the tastes and preferences of their final consumers. This has been found to be a big challenge to the sustainability of the system.

There is low $(5 \%)$ value addition in the camel milk value chain implicating negligible $(<1 \%)$ access of the milk to national, regional, and international markets. This is due mainly to a lack of skills and knowledge about a modernized camel milk value chain. We show that this is due to weak relationships among the value chain actors, exacerbated by weak regulatory mechanisms in the county. Our observations are in line with studies conducted by Nato et al. (2018) that revealed that such milk production methods contribute to an increased bacterial load in traditional camel milk production due to low compliance with hygiene practices, subjecting the product to poor quality and safety standards. The other challenge is weak networks among the milk producers and other support institutions. However, our study shows a similar trend in the value chain to that reported by other studies in similar regions of Africa such as Morocco, Djibouti, Mauritania, and Sudan (Idris, 2011), and Ethiopia (Dandesa, 2017). The current production and marketing practices make it difficult to sustain a camel milk value chain in the county. Our study also concurs with other findings that indicate that the constraints to milk marketing in Isiolo County are mainly due to poor hygiene practices and low capacities for milk processing and marketing, all of which exacerbate low incomes due to low production (Wayua et al., 2012).

Our study is also in line with the findings of Colonna et al. (2013), who indicate that a value chain involves many value chain actors who have significant roles in characterizing complex networks and relationships among actors. Although livestock production and the subsequent value chains offer good opportunities for the pastoral communities, there is a weak relationship between the input suppliers and the producers. Our study also concurs with studies that show weak interfarm linkages and uncoordinated market strategies in many undeveloped economies (Anastasiadis \& Poole, 2015). Our findings also concur with other studies that observe challenges in regulatory mechanisms due to informal marketing systems exacerbated by poor control mechanisms (Colonna et al., 2013; Ericksen, 2008a; Kirwan \& Maye, 2013).

This study also agrees with Herrero and Thornton (2013), who point out that a food system can only be sustainable if social, institutional, and political support are provided to the adaptive capacity of the local value chains. Our study has shown that a camel milk value chain is a potential source of pastoral livelihoods and accommodates varied categories of actors in the chain. It is also in line with other studies that have indicated that even resource-poor households involved in the value chain received earnings from the sale of milk (Nato et al., 2018; Noor et al., 2013). It is important to note there is no restriction or limit to enter into the system. This has stimulated increasing interests in the development of the camel milk value chain by many micro-actors, stakeholders, and development agencies, as also indicated by Odongo et al., 2016; Wayua et al., 2012. Although the traditional milk production and preservation methods may suffice for the domestic market, this practice is not sustainable, and it does not conform to global standards. The existing regulatory frameworks are weak and fail to recognize camel milk as dairy milk. Specifically, the KDB Policy of 2017 and related legislation refer dairy as the "milk from cow" 
(GOK, 2017b). These pose a great challenge to the integration of the county's camel milk value chain into the national dairy system that requires quality and safety controls of milk products to meet those of national, regional, and international markets. According to the 2012 Kenya Public Health Act and the 2017 dairy industry regulations (GOK, 2017), all dealers in milk products are supposed to have adequate skills for clean milk production while adhering to quality safety standards and to have the requisite licenses and certificates obtained after the inspection and approval of their trade practices. We also found the 2008 Kenya national livestock policy [NLP] on to which the county regulatory frameworks (e.g. Isiolo County Sales Yard Act, 2016; Isiolo County Climate Change and Adaptation, 2016) are anchored, have become obsolete and outdated. There is also inadequate synergy among the existing pieces of legislation envisaged to boost the livestock industry. The Isiolo County sector development plans are supposed to match the national policies that cover a period of 10 years. Thereafter, the policies are reviewed depending on prevailing conditions and need. One can draw assumptions from the fact that the lack of awareness of the existing policies and legislation are due to weak extension services, consultative planning mechanisms, and capacitybuilding initiatives. This is also evidenced by the fact that the major role of the county is revenue collection (48\%) and only $3 \%$ in policy implementation. Our study, therefore, agrees with the findings by Kirwan and Maye (2013) that there is a need to address the question of how local value chains can be structured and coordinated for sustainability.

Although there are many institutions providing regulatory and support services to the county's camel milk value chain, the system is still facing problems of low production and lack of skills in processing milk and milk products, evidenced by high post-harvest losses, to meet a sustainable and viable business environment. The identified regulatory frameworks for the system in the county, which included the Kenya Dairy Board [KDB]), Public Health Department, Kenya Bureau of Standards [KEBS], National Environment Management Authority [NEMA], and the national and county governments that are supposed to provide an enabling environment for the system, are also not well coordinated. Despite the existence of all these frameworks, there are no control mechanisms in the camel milk value chain to enhance a viable business environment.

The FAO's (Neven, 2014) sustainable food value chain [SFVC] concept is applied to regional and global levels, with a country's entire product measured on performance and assessed on the product's aggregated levels. Hence, the concept focuses more on efficiency improvements that increase consumer food availability than on locally instituted mechanisms to ensure the objectives of sustainable potential value chains. We find that this concept also does not recognize regulatory aspects as the main foundation for achieving a sustainable value chain. The main concern, therefore, is embedded in the fact that there are no strong regulatory frameworks in place to enhance the sustainability of the promising value chains in Isiolo County. This phenomenon disrupts a consistent and reliable marketing system because it makes it more difficult to meet the required standards to access national and regional markets to enhance a sustainable system.

\section{Conclusion and Recommendations}

The camel milk value chain incorporates the most vulnerable populations in the society, such as women and youth, into the system. Although the value chain is similar to those revealed in other studies, the system is operating in an informal marketing structure with loosely connected value chain actors. We observe there is a substantial challenge for the various players to achieve a modernized system in the production, processing, and marketing of camel milk products. These include weak connections among the actors and a lack of skills and capacities that accrue from a large number of value chain actors, such as women who lack formal education but play critical roles in milk handling and processing activities. There is a high volume of milk that spoils or goes to waste due to poor milk handling techniques and low value addition. The lack of coordination and poor institutional connectivity were major issues in enhancing a well-regulated system. Nevertheless, there is great 
potential for the camel milk value chain in the county for domestic, national, and international markets.

Our study recommends certain policy options to strengthen a well regulated and functional camel milk value chain in Isiolo County. These include to (1) establish a camel milk dairy board that would help regulate the system more effectively and efficiently, (2) strengthen the institutional networks among the value chain actors, (3) enhance inclusivity in decision-making and control measures through gender mainstreaming particularly to uphold women's values, and (4) build capacity of the actors for an enhanced and sustainable system.

In order to put the county on a global camel milk products market standard, there is a need for operational control mechanisms that include establishing technical milk inspectors and laboratory technicians for milk quality and safety control measures. There is also need for adequate extension service providers to build the capacity of camel milk micro-actors on camel husbandry and health regulations. This will also help put in place the residue monitoring plan for the camel milk value chain that is compliant with the national, regional, and global standards.

\section{Model for Sustainable Camel Milk Value Chain in Isiolo County}

In this section, we present a model for a well regulated camel milk value chain in Isiolo County to improve on the current informal marketing system. The conceptual model is modified from the FAO (Neven, 2014) sustainable food value chains concept (SFVC). We identify the major drivers of the camel milk value chain by identifying their household socio-demographic and socio-economic status, and assess the value chain system, institutional arrangements, and regulatory frameworks influencing the system. These will enhance a commercially oriented and well-structured value chain with enhanced adaptation strategies and regulatory frameworks. The outcome is a sustainable camel milk value chain determined by increased productivity, enhanced capacities of the value chain actors with strong networks, increased market access, strengthened institutional arrangements, and effective regulatory mechanisms (Figure 4).
At the county level, the model recommends the development of a camel milk policy that puts in place strong institutional arrangements by establishing a camel dairy board to provide guidance on camel milk marketing legislation. This board would also establish coordination mechanisms aligned with the national livestock policy and food systems strategies. The model recognizes the need for coordination and knowledge transfer to various value chain actors through capacity-building that will ultimately trigger transformative innovations in the system. In order to determine the sustainability of the system, the model recommends that the camel milk value chain in the county be anchored on national frameworks, such as KEBS quality and safety standards and the national environmental frameworks that include the climate change policy and the ending drought emergencies (EDE) strategies. At the regional level, we recommend that the value chain align with regional agreements such as the Intergovernmental Authority on Development (IGAD), Common Markets for Eastern and Southern Africa (COMESA), and East African Community (EAC) for compliance in terms of quality and safety measures, as well as adherence to environmental integrity. Finally, we recommend all these frameworks be aligned with global food system policies and agreements, such as the United Nations Sustainable Development Goals (SDGs), climate change frameworks, and World Trade Organization (WTO) standards, in order to achieve a sustainable camel milk value chain in Isiolo County and other areas of Africa with similar value chains.

\section{Recommendations for Further Research}

A camel milk value chain in Isiolo County is critical to cushioning the pastoral community's requirements for food and other social amenities. The national and county demand for the contribution of camel milk to GDP and revenue is also raising concern. Thus there is a need to carry out research to understand the dynamics of the camel milk value chain and explore opportunities to modernize the value chain and enhance a sustainable system. Emerging camel diseases are also becoming more prevalent and affect milk production, which ultimately translates to low gains to meet the socio- 
economic needs of the chain's dependents. Therefore, more research will be required on currently emerging diseases, such as camel sudden deaths and Rift Valley fever, which are also trade-sensitive diseases. Land use is a major concern in pastoral production systems, since most of the land tenure is under communal grazing system. There is a need for further research to understand the implications

Figure 4. Model for Sustainable Camel Milk Value Chain in Isiolo County, Kenya

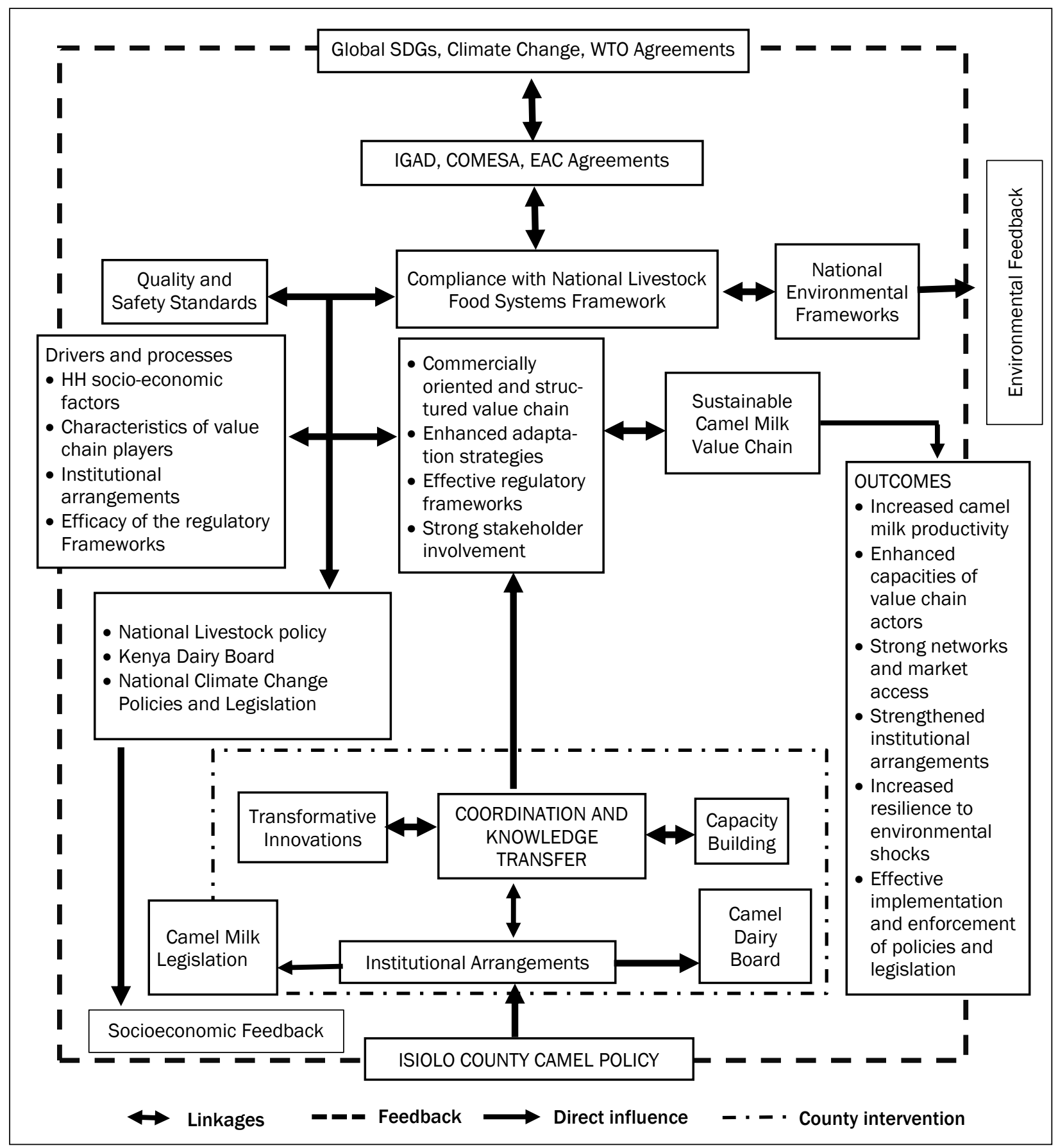

Note: IGAD=Intergovernmental Authority on Development; COMESA=Common Markets for Eastern and Southern Africa; KEBS=Kenya Bureau of Standards. 
of the Community Land Act of 2016 in order to strengthen communal land ownership and sustainable production systems. Further research should also focus on frameworks for regional coordination and integration mechanisms to effectively implement and enforce global standards for quality and safety control measures in a camel milk value chain.

\section{Acknowledgements}

We extend our gratitude to all the household respondents interviewed during the study and the four research assistants who provided valuable information and translations respectively. Further appreciation is also extended to the county and sub-county departmental heads, value chain organizations' groups, and various key informants for offering their valuable time and good ideas, without which this study would not have been completed. We are also highly indebted to all the nongovernmental organizations, faith-based organizations, and community-based organizations for sharing reports and experiences pertaining to the camel milk value chain in Isiolo County. Finally, we wish to recognize the contributions of the academic staff and fellow students of the Centre for Advanced Studies in Environmental Law and Policy, University of Nairobi.

\section{References}

Anastasiadis, F., \& Poole, N. (2015). Emergent supply chains in the agrifood sector: Insights from a whole chain approach. Supply Chain Management, 20(4), 353-368. https://doi.org/10.1108/SCM-08-2014-0259

Behnke, R., \& Muthami, D. (2011). The contribution of livestock to the Kenyan economy (IGAD Livestock Policy Initiative Working Paper No. 03-11). Intergovernmental Authority on Development Livestock Policy Initiative. https://cgspace.cgiar.org/bitstream/handle/10568/24972/IGAD LPI WP 03-11.pdf

Colonna, P., Fournier, S., Touzard, J.-M., Abecassis, J., Broutin, C., Chabrol, D., Champenois, A., Deverre, C., François, M., Lo Stimolo, D., Méry, V., Moustier, P., \& Trystram, G. (2013). Food systems. In C. Esnouf, M. Russel, \& N. Bricas (Eds.), Food system sustainability: Insights from duALIne (pp. 69-100). Cambridge University Press. https://doi.org/10.1017/CBO9781139567688.006

County Government of Isiolo. (2018). Isiolo County Integrated Development Plan [CIDP]. 2018-2022. https://repository.kippra.or.ke/handle/123456789/1409

Dandesa, T., Korecha, D., Nigatu, L., \& Cheneka, B. R. (2017). Assessment of climatic variability and development of localized climate prediction method for livestock production in Borana Area, Southern Ethiopia. Environmental Science: An Indian Journal, 13(3), 137. https://www.tsijournals.com/articles/assessment-of-climatic-variability-anddevelopment-of-localized-climate-prediction-method-for-livestock-production-in-borana-area-html

Demissie, B., Komicha, H. H., \& Kedir, A. (2017). Production and marketing of camel milk in Ethiopia. African Journal of Marketing Management, 9(7), 98-106. https://doi.org/10.5897/AJMM2016.0500

Downie, K. (2011). A review of good practice and lessons learned in programming for AS AL populations in the Horn of Africa. UNICEF ESARO.

Ericksen, P. J. (2008a). Conceptualizing food systems for global environmental change research. Global Environmental Change, 18(1), 234-245. https://doi.org/10.1016/i.gloenvcha.2007.09.002

Ericksen, P. J. (2008b). What is the vulnerability of a food system to global environmental change? Ecology and Society, 13(2), Article 14. https://doi.org/10.5751/ES-02475-130214

Familiar Calderon, J. (2018). Colombia-Mainstreaming Sustainable Cattle Ranching Project: Restructuring (English) (Report No. RES30919). The World Bank. http://documents.worldbank.org/curated/en/965391516379363201/ColombiaMainstreaming-Sustainable-CattleRanching-Project-restructuring

Farmer, E., \& Mbwika, J. (2012). End market analysis of Kenyan livestock and meat: A desk study. ACDI/VOCA. https://www.marketlinks.org/resources/end-market-analysis-kenyan-livestock-and-meat-desk-study 
Francis, M., Simons, D., Bourlakis, M. (2008). Value chain analysis in the UK beef foodservice sector. Supply Chain Management, 13(1), 83-91. https://doi.org/10.1108/13598540810850346

Government of Kenya [GOK]. (2012). National policy for the sustainable development of Northern Kenya and other arid lands (Sessional Paper No. 8). https:// repository.kippra.or.ke/handle/123456789/1020

GOK. (2013). National Climate Change Action Plan 2013-2017. https://www.fao.org/faolex/results/details/en/c/LEXFAOC147843/

GOK. (2017). Dairy Industry Act. Chapter 336. Revised Edition 2012 [1984]. https://www.ecolex.org/details/legislation/dairy-industry-act-cap-336-lex-faoc063519/

Harison, K., Mark, B., \& Imwati, A. (2017). Spatial variability of malnutrition and predictions based on climate change and other causal factors: A case study of North Rift ASAL counties of Kenya. Journal of Earth Science \& Climatic Change, 8(10), Article 416. https://doi.org/10.4172/2157-7617.1000416

Herrero, M., \& Thornton, P. K. (2013). Livestock and global change: Emerging issues for sustainable food systems. Proceedings of the National Academy of Sciences of the United States of America, 110(52), 20878-20881. https://doi.org/10.1073/pnas.1321844111

Hussein, M. U. (2015). Influence of indigenous drought management strategies on the livelihood system of pastoralists in Mandera west sub county, Kenya. University of Nairobi. http://hdl.handle.net/11295/90561

Idris, A. (2011). Taking the camel through the eye of a needle: Enhancing pastoral resilience through education policy in Kenya. Resilience: Interdisciplinary Perspectives on Science and Humanitarianism, 2, 25-38. https://dlci-hoa.org/assets/upload/combined-documents/20200804031525956.pdf

Ingram, J. (2011). A food systems approach to researching food security and its interactions with global environmental change. Food Security 3, 417-431. https://doi.org/10.1007/s12571-011-0149-9

Kenya National Bureau of Statistics [KNBS]. (2020). 2019 Kenya population and housing census: Distribution of livestock population by type, fish ponds and fish cages by county and sub county. https://open.africa/dataset/2019-kenya-populationand-housing-census/resource/bf994988-4fe3-4443-bace-6513f35c44ed

McGinnis, M. D. \& Ostrom, E. (2014). Social-ecological system framework: Initial changes and continuing challenges. Ecology and Society, 19(2), Article 30. https://doi.org/10.5751/ES-06387-190230

Mwanyumba, P. M., Wahome, R. W., MacOpiyo, L., \& Kanyari, P. (2015). Pastoralist livelihoods, livestock herd dynamics and trade in Garissa county, Kenya In the arid and semi-arid areas of northeastern Kenya. Pastoralism, 5 , Article 26. https://doi.org/10.1186/s13570-015-0045-6

National Drought Management Authority, Ministry of Devolution and Planning. (2015). Ending drought emergencies common programme framework. http://www.ndma.go.ke/index.php/resource-center/category/43-ending-drought-emergencies

Nato, S. M., Matofari, J. W., Bebe, B. O., \& Huelsebusch, C. (2018). Effect of predisposing factors on microbial loads in camel milk along the pastoral dairy value chain in Kenya. Pastoralism, 8, Article 16. https://doi.org/10.1186/s13570-018-0123-7

Ndiritu, S. W. (2020). Beef value chain analysis and climate change adaptation and investment options in the semi-arid lands of northern Kenya. Journal of Arid Environments, 181, Article 104216. https://doi.org/10.1016/j.jaridenv.2020.104216

Neven, D. (2014). Developing sustainable food value chains: Guiding principles. Food and Agriculture Organization of the United Nations [FAO]. http://www.fao.org/3/i3953e/i3953e.pdf

Noor, I. M., Guliye, A. Y., Tariq., M., \& Bebe, B.O. (2013). Assessment of camel and camel milk marketing practices in an emerging peri-urban production system in Isiolo County, Kenya. Pastoralism, 3, Article 28. https://doi.org/10.1186/2041-7136-3-28

Odhiambo, M. O. (2013). The ASAL policy of Kenya: Releasing the full potential of arid and semi-arid lands-An analytical review. Nomadic Peoples, 17(1), 158-165. https://doi.org/10.3167/np.2013.170110

Odongo, N. O., Lamuka, P. O., Abong, G. O., Matofari, J. W., \& Abey, K. A. (2016). Physiochemical and microbiological post-harvest losses of camel milk along the camel milk value chain in Isiolo, Kenya. Current Research in Nutrition and Food Science, 4(2). 80-89. https://doi.org/10.12944/CRNFSJ.4.2.01 
Rashid, H. H. (2014). Land use conflicts and opportunities in a livestock market: Case study of Garissa market. University of Nairobi Research Archive. http://erepository.uonbi.ac.ke/handle/11295/95389

Reay, D. S., Warnatzsch, E. A., Craig, E., Dawson, L., George, S., Norma, R., \& Ritchie, P. (2020). From farm to fork: Growing a Scottish food system that doesn't cost the planet. Frontiers in Sustainable Food Systems, 4, Article 72. https://doi.org/10.3389/fsufs.2020.00072

Shukla, M., \& Jharkharia, S. (2013). Agri-fresh produce supply chain management: A state-of-the-art literature review. International Journal of Operations \& Production Management, 33(2), 114-158. https://doi.org/10.1108/01443571311295608

Thornton, P. K., Ericksen, P. J., Herrero, M., \& Challinor, A. J. (2014). Climate variability and vulnerability to climate change: A review. Global Change Biology, 20(11), 3313-3328.: https://doi.org/10.1111/gcb.12581

Wayua, F. O., Okoth, M. W., \& Wangoh, J. (2012). Survey of postharvest handling, preservation and processing practices along the camel milk value chain in Isiolo District, Kenya. African Journal of Food, Agriculture, Nutrition and Development, 12(7), 6897- 6912. https://doi.org/10.18697/ajfand.55.10735

Willet, W., Rockström, J., Loken, B., Springmann, M., Lang, T., Vermeulen, S., Garnett, T., Tilman, D., DeClerck, F., Wood, A., Jonell, M., Clark, M., Gordon, L. J., Fanzo, J., Hawkes, C., Zurayk, R., Rivera, J. A., De Vries, W., Sibanda, L. M., ... Murray, J. L. (2019). Food in the Anthropocene: The EAT-Lancet Commission on healthy diets from sustainable food systems. The Lancet, 393(10170), 447-492. https://doi.org/10.1016/S0140-6736(18)31788-4

Yilma, Z., Hailu, Y., Wolkaro, T., \& Eshetu, M. (2017). The Ethiopian dairy value chain with particular focus on cattle and camel milk: Current scenarios and investment opportunities. East African Journal of Sciences, 11(2), 81-92. https://www.researchgate.net/publication/330663240 